Sebastian Stępień, Katarzyna Smędzik-Ambroży, Marta Guth

\title{
Oddziaływanie Wspólnej Polityki Rolnej na zrównoważenie ekonomiczno-społeczne gospodarstw rolnych na przykładzie Polski*
}

Streszczenie: Koncepcja zrównoważonego rozwoju powstała w drugiej połowie XX w. i odegrała istotną rolę w określaniu relacji pomiędzy wzrostem gospodarczym, rozwojem społecznym a dbałością o środowisko naturalne. W pierwszym etapie tworzenia się paradygmatu uznawano wyższość kwestii środowiskowych, jednak wraz z postępującą globalizacją coraz częściej zaczęły ujawniać się negatywne efekty natury ekonomiczno-społecznej, związane z nierównomiernych podziałem dochodu, problemem ubóstwa i wykluczenia społecznego. Kwestia ta została dostrzeżona również na poziomie Unii Europejskiej, m.in. poprzez kreowanie polityk sektorowych, w tym Wspólnej Polityki Rolnej (WPR). Jednym z ważniejszych założeń WPR jest zagwarantowanie godziwego poziomu życia ludności rolniczej i ma ono być realizowane poprzez różne formy wsparcia. Dla podtrzymania zrównoważonego rozwoju należy przyjąć, że mechanizmy wsparcia powinny być tak skonstruowane, aby zapewnić równocześnie wysoki poziom dochodów rolniczych (element ekonomiczny), relatywnie równy ich podział wśród producentów rolnych (element społeczny) i dbałość o środowisko naturalne (element środowiskowy). Celem artykułu jest określenie wpływu WPR na poziom zrównoważenia ekonomiczno-społecznego gospodarstw rolnych w Polsce. Autorzy stawiają hipotezą, że istniejące rozwiązania służą osiąganiu zrównoważenia ekonomicznego (określonego przez relację dochodów rolniczych do pozarolniczych), nie zmniejszają natomiast dysproporcji dochodowych wewnątrz sektora rolnego, co jest elementem zrównoważenia społecznego. W publikacji wykorzystano krytyczną analizę literatury

Dr hab. Sebastian Stępień, prof. UEP, Katedra Makroekonomii i Gospodarki Żywnościowej, Uniwersytet Ekonomiczny w Poznaniu, sebastian.stepien@ue.poznan.pl; dr Katarzyna Smędzik-Ambroży, Katedra Makroekonomii i Gospodarki Żywnościowej, Uniwersytet Ekonomiczny w Poznaniu, katarzyna. smedzik@ue.poznan.pl; dr Marta Guth, Katedra Makroekonomii i Gospodarki Żywnościowej, Uniwersytet Ekonomiczny w Poznaniu, marta.guth@ue.poznan.pl.

* Artykuł powstał w ramach grantu badawczego pt. „Determinanty bezpieczeństwa żywnościowego i zrównoważonego rozwoju drobnotowarowych gospodarstw rolnych w Polsce na tle regionów Unii Europejskiej", finansowanego przez Narodowe Centrum Nauki (umowa nr 2016/21/B/HS4/00653). 
przedmiotu, metaanalizę, metody wnioskowania indukcyjnego, a ponadto wybrane metody analizy ilościowej regresji i analizy panelowej. Zakres podmiotowy obejmuje gospodarstwa rolne należące do systemu FADN, a czasowy - lata 2004-2013.

Słowa kluczowe: zrównoważenie ekonomiczno-społeczne, Wspólna Polityka Rolna, gospodarstwa FADN, Polska.

\section{Wprowadzenie}

Pojęcie zrównoważenia społeczno-ekonomicznego (lub rozwoju zrównoważonego pod względem ekonomicznym i społecznym) jest bardzo obszerne i w zależności od przyjętej koncepcji wymienia się różne cechy opisujące ten stan. Sama idea pojawiła się jako próba udzielenia odpowiedzi na zespół zagrożeń, które dostrzeżono w wysokim wzroście demograficznym, przy szybkim zużywaniu zasobów naturalnych, narastającym zanieczyszczeniu środowiska, niezaspokajaniu podstawowych potrzeb coraz większych grup ludzi, a także głębokiej destabilizacji systemów przyrodniczych i społeczno-ekonomicznych (Zabłocki 2002). Podstawy definicji rozwoju zrównoważonego zostały sformułowane w końcowym raporcie powołanej przez ONZ Światowej Komisji Środowiska i Rozwoju, zwanym także raportem Brundtland (od nazwiska przewodniczącej Komisji). Wskazano wówczas, że rozwój zrównoważony łączy w sobie potrzeby realizacji potrzeb obecnej generacji bez ograniczania praw przyszłych pokoleń do zaspokajania ich aspiracji (World Commission on Environment and Development 1987). Kilka lat później (w 1992), podczas konferencji ONZ w Rio de Janeiro „Środowisko i Rozwój” (określanej także jako „Szczyt Ziemi”) opracowano szeroką koncepcję rozwoju zrównoważonego (United Nations 1992). Zgodnie z nią jest to strategia, która zakłada odpowiednio ukształtowane relacje pomiędzy wzrostem gospodarczym, dbałością o środowisko i sferę społeczną (Sebaldt 2002). Warto podkreślić, że o ile we wcześniejszych dokumentach punkt ciężkości dotyczył kwestii środowiskowych (stąd często stosowane wówczas określenie ekorozwoju), o tyle w „deklaracji z Rio” element społeczny stał się równoważny. Tym samym istotną rolę przypisywano działaniom mającym na celu zwiększanie spójności społecznej, w tym m.in. ograniczanie rozwarstwienia dochodowego, wyrównywanie szans i przeciwdziałanie marginalizacji, dostęp do zatrudnienia, edukacji i ochrony zdrowia.

Koncepcja zrównoważonego rozwoju ukierunkowana na wzrost gospodarczy, rozwiązywanie problemów społecznych i środowiskowych stała się częścią składową Traktatu Amsterdamskiego UE z 1997 r. W dokumencie podkreślono, że rozwój Unii Europejskiej w długiej perspektywie będzie możliwy tylko przy wspólnym udziale trzech czynników: wzrostu gospodarczego, spójności społecznej 
i ochrony środowiska naturalnego (Commission of the European Communities 2001). W 2001 r. Rada Europejska przyjęła konkluzje do zaproponowanego przez Komisję Europejską dokumentu A Sustainable Europe for a better world: A European Strategy for Sustainable Development (tzw. Strategia Goeteborska), który stał się podstawą stworzenia pierwszej strategii zrównoważonego rozwoju UE (EU SDS) (Hontelez, Buitenkamp 2006). Współczesna wizja tej idei, realizowana w ramach Strategii Europa 2020, obejmuje wzajemnie powiązane ze sobą następujące priorytety (European Commission 2010):

- rozwój inteligentny, oparty na wiedzy i innowacjach;

- rozwój sprzyjający włączeniu społecznemu, przy wysokim poziomie zatrudnienia i zapewnieniu spójności społecznej i terytorialnej;

- rozwój zrównoważony, przy wsparciu gospodarki efektywniej korzystającej z zasobów, bardziej przyjaznej środowisku i bardziej konkurencyjnej.

Ważne jest przy tym, aby korzyści ze wzrostu gospodarczego rozkładały się równo w całej Unii Europejskiej, w tym w regionach najbardziej oddalonych.

Poza wymienionymi strategiami koncepcja zrównoważonego rozwoju jest obecna również w innych dokumentach i inicjatywach UE, m.in. białych i zielonych księgach, komunikatach Komisji Europejskiej czy też opiniach Europejskiego Komitetu Ekonomiczno-Społecznego. W każdym z tych dokumentów kładzie się nacisk na element gospodarczy - rozumiany jako wypracowanie relatywnie wysokiego tempa wzrostu PKB, społeczny - określony poprzez sprawiedliwość i spójność społeczną, zrównoważoną redystrybucję dochodów i konsumpcję, integrację społeczną, zdrowie publiczne i wyzwania w zakresie ubóstwa, oraz środowiskowy - oceniany przez pryzmat ochrony przyrody i zarządzania zasobami naturalnymi, zmian klimatu, czystej energii i zrównoważonego transportu. Warto jednocześnie podkreślić, że koncepcja zrównoważonego rozwoju wymaga zintegrowanego podejścia na wszystkich szczeblach i we wszystkich politykach sektorowych. Przykładem jest Wspólna Polityka Rolna (WPR), dla której jednym z głównych celów jest zagwarantowanie godziwego poziomu życia społeczności rolniczej (Massot 2016), m.in. poprzez stabilne dochody i poprawę warunków funkcjonowania na obszarach wiejskich (tworzenie infrastruktury, przedsiębiorczości, usług itp.), przy poszanowaniu środowiska naturalnego.

Celem artykułu jest określenie wpływu WPR na poziom zrównoważenia ekonomiczno-społecznego gospodarstw rolnych w Polsce (zrównoważenie środowiskowe jest przedmiotem osobnego opracowania). Autorzy stawiają hipotezę, że istniejące rozwiązania WPR służą osiąganiu zrównoważenia ekonomicznego (określonego przez relację dochodów rolniczych do pozarolniczych), nie zmniejszają natomiast dysproporcji dochodowych wewnątrz sektora rolnego, co jest elementem zrównoważenia społecznego (nie oznacza to jednak, że nie poprawiają innych elementów 
tego zrównoważenia, takich jak warunki pracy czy dostęp do infrastruktury). Mówiąc inaczej, dzięki wsparciu średni dochód rolniczy gospodarstw zbliża się do przeciętnego dochodu z działów pozarolniczych, jednak pomiędzy gospodarstwami małymi, średnimi i dużymi dystrybucja tego wsparcia jest wysoce zróżnicowana. I chociaż w ujęciu absolutnym może następować poprawa jakości życia w każdej z wymienionych grup, to w rzeczywistości dochodzi do relatywnej deprywacji najmniejszych podmiotów ${ }^{1}$. W publikacji wykorzystano krytyczną analizę literatury przedmiotu, metaanalizę, metody wnioskowania indukcyjnego, a ponadto wybrane metody analizy ilościowej - regresji i analizy panelowej. Zakres podmiotowy obejmuje gospodarstwa rolne należące do sytemu FADN, a czasowy - lata 2004-2013.

\section{Pomiar zrównoważenia ekonomiczno-społecznego - przegląd literatury przedmiotu}

Nawiązując do wskazanej we wstępie istoty zrównoważonego rozwoju, należy zaznaczyć, że rozwój społeczno-gospodarczy musi stać się warunkiem dla zapewnienia środowiska sprzyjającego funkcjonowaniu człowieka oraz poprawie jakości życia. Wymiar ekonomiczny rozwoju zrównoważonego ma bazować na założeniu, że dwa pozostałe wymiary tego rozwoju, tzn. społeczny i ekologiczny, nie są hamulcami postępu, tylko jego stymulatorami. Z kolei realizacja celów środowiskowych nie może powodować niepożądanego zmniejszania tempa wzrostu gospodarczego ani poszerzać marginesu ubóstwa, czyli pogłębiania lub powstawania nowych napięć społecznych (Mazur-Wierzbicka 2006). Idea zrównoważonego rozwoju nie jest bowiem sprzeczna ze wzrostem dobrobytu, lecz akcentuje konieczność optymalizacji gospodarki w aspekcie jakościowej (duchowej) sfery życia człowieka i minimalizacji negatywnego wpływu działalności gospodarczej na środowisko. W odniesieniu do rolnictwa koncepcja zrównoważonego rozwoju zakłada jednoczesne dążenie do poprawy warunków życia ludności i prowadzenia działalności gospodarczej na obszarach wiejskich, przy nienaruszaniu specyficznych zasobów wsi takich jak środowisko naturalne, krajobraz i dziedzictwo kulturowe (Żmija 2014). Warunkiem koniecznym takiego rozwoju staje się podtrzymywanie lub rozwijanie kapitału ekonomicznego i społecznego w taki sposób, aby dochody i jakość życia rolników i innych mieszkańców wsi były porównywalne do tych uzyskiwanych w działach pozarolniczych.

Po przejściu do opisu wybranych mierników (wskaźników) rozwoju zrównoważonego uwaga autorów zostanie skupiona na elementach ekonomicznym

1 Problem względnej deprywacji gospodarstw rolnych (tyle że w ujęciu relacji dochodów gospodarstw rolnych do dochodów pozarolniczych) został opisany m.in. w pracach Bazylego Czyżewskiego i Agnieszki Poczty-Wajdy (por. Czyżewski 2017; Poczta-Wajda 2016). 
i społecznym, z pominięciem kwestii pomiaru zrównoważenia środowiskowego (nie jest to bowiem celem opracowania). I tak można stwierdzić, że podstawowymi i najczęściej wykorzystywanymi miarami efektu ekonomicznego są wskaźniki ilościowe wzrostu produkcji wytworzonej bądź wskaźniki wzrostu ilościowego konsumpcji (a więc produkcji sprzedanej). Na poziomie makroekonomicznym przyjmują one postać produktu krajowego brutto (względnie produktu narodowego brutto lub dochodu narodowego). W skali mikroekonomicznej ekonomiści posługują się wielkością dochodu na osobę w gospodarstwie domowym, wielkością wydatków gospodarstwa, rzadziej poziomem płac. Wśród innych miar ładu ekonomicznego stosuje się m.in. wskaźniki zatrudnienia i aktywności zawodowej, wydajności siły roboczej, wskaźniki kapitałochłonności majątku trwałego i energochłonności, poziom inwestycji, nakłady na działalność badawczo-rozwojową (GUS - Urząd Statystyczny w Katowicach 2011; Eurostat 2017).

Ponieważ na dobrobyt oddziałuje wiele czynników o charakterze tak mierzalnym, jak niemierzalnym, a decydujących o jakości życia (takich jak jego długość, stan zdrowia, warunki mieszkaniowe, edukacja i kultura, prawa człowieka), został stworzony katalog miar uwzględniających te elementy. Wiele z nich odnosi się do kwestii sprawiedliwego podziału dobrobytu i pomiaru równomierności rozkładu dochodów. Najpowszechniej stosowany jest współczynnik Giniego oparty na krzywej Lorenza, który jest miarą koncentracji (nierównomierności) rozkładu dochodów w badanej grupie (Peacock, Hoover, Kilian 1988). Na bazie współczynnika Giniego Amartya Sen opracował miarę dobrobytu uwzględniającą poziom i rozkład dochodu per capita. Okazuje się, że wysoki poziom dochodu per capita nie jest równoznaczny $\mathrm{z}$ wysokim poziomem rozwoju społeczno-gospodarczego. Kraje o niższych dochodach, ale kładące nacisk na egalitarny ich podział, oraz państwa o wysokim poziomie dochodów na osobę ze sporymi dysproporcjami w ich rozkładzie mogą zostać uznane za osiągające ten sam poziom dobrobytu (Sen 1992). Innym przykładem jest Indeks Trwałego Dobrobytu Ekonomicznego (index of sustainable economic welfare; ISEW) opracowany przez Hermana E. Daly'ego i Johna B. Cobba w 1989 r. W mierniku tym punktem wyjścia są indywidualne wydatki na konsumpcję skorygowane m.in. o straty wynikające z nierównomiernej dystrybucji dochodów (Graczyk 2007). Poza kwestią nierówności podziału dochodów zrównoważony rozwój w ujęciu społecznym mierzy się za pomocą następujących elementów: dostęp do rynku pracy (w tym poziom bezrobocia), dostęp do edukacji, jakość zdrowia publicznego, zmiany demograficzne (np. współczynnik przyrostu naturalnego, wskaźnik migracji), bezpieczeństwo publiczne oraz zrównoważone wzorce konsumpcji (GUS - Urząd Statystyczny w Katowicach 2011; Eurostat 2017).

Specjalny zestaw wskaźników zrównoważenia społeczno-ekonomicznego został opracowany dla oceny funkcjonowania gospodarstw rolnych. Kryterium oceny 
ekonomicznej stanowią najczęściej wyniki produkcyjne (np. wielkość przychodów, dochodów i kosztów produkcji) i oparte na nich wskaźniki opłacalności, płynności, stabilności i produktywności ${ }^{2}$ (Latruffe 2010). Dodatkowe kryterium, jakim jest „autonomia”, proponuje Hartmut Bossel (Bossel 1999). Owa autonomia (wolność) może być postrzegana jako uniezależnienie się od zakupu środków produkcji z zewnątrz, co oznacza, że gospodarstwa są mniej podatne na wszelkie wahania cen środków produkcji. Autonomię można także oceniać pod kątem stopnia zadłużenia czy też wpływu subsydiów na wynik ekonomiczny. W końcu, autonomia może być związana z możliwością dywersyfikacji dochodów - im wyższa, tym większa autonomia, przy czym dochód może być dywersyfikowany poprzez różnicowanie produkcji rolnej albo poprzez uzyskiwanie dochodów pozarolniczych. Wymiar ekonomiczny może być również utożsamiany z pojęciem żywotności gospodarstwa rolnego, czyli zdolności do trwania w długim okresie w zmiennych warunkach rynkowych (Latruffe i in. 2016).

Aspekt społeczny zrównoważenia dotyczy oceny sposobu życia rodzin rolniczych i obejmuje: edukację, warunki pracy (w tym czas pracy) oraz jakość życia (stopień włączenia lub wykluczenia społecznego) (Lebacq, Baret, Stilmant 2013). Nora van Cauwenbergh rozszerza tę listę o stan zdrowia, równość płci i dostęp do usług i infrastruktury na wsi. W szerszym kontekście można także mówić o jakości życia na obszarach wiejskich (uwzględniając dziedzictwo kulturowe, tradycje i wartości estetyczne), dostępie do zatrudnienia i ekousług oraz zdrowej żywności (van Cauwenbergh i in. 2007).

Tylko część z omówionych wyżej miar jest stosowana w praktyce gromadzenia danych. Przykładowo, w bazie rachunkowości rolniczej FADN (opracowanej dla gospodarstw rolnych w UE) są dostępne informacje na temat wielkości przychodów i dochodów z produkcji rolnej, wielkości zatrudnienia, wyposażenia w maszyny i urządzenia, poziomu inwestycji i zadłużenia. Większosśc krajów członkowskich gromadzi również dane na temat dostępu do edukacji, z drugiej strony zaledwie jeden kraj prowadzi statystyki warunków pracy i jakości życia, a żaden nie obejmuje kwestii zaangażowania rolników w społeczności lokalnej (Vrolijk, Poppe, Keszthelyi 2016). Trzeba jednak zauważyć, że pomiar elementów społecznych jest dużym wyzwaniem, ponieważ wiele z nich ma charakter jakościowy i kulturowy, a stąd subiektywny.

2 Opłacalność jest szacowana na podstawie porównania przychodów i kosztów produkcji jako ich różnica lub relacja bądź też poprzez różne kategorie dochodu rolniczego; płynność mierzy zdolność gospodarstwa do spłaty krótkoterminowych zobowiązań (może być mierzona stosunkiem gotówki do zobowiązań krótkoterminowych); stabilność wyrażona jest przez wielkość majątku trwałego i jego udział w łącznym bilansie gospodarstwa, a produktywność to miara zdolności generowania produkcji przez czynniki produkcji (relacja efektu do nakładu danego czynnika produkcji lub wskaźnik total factor productivity - TFP). 


\section{Metodologia badania}

W pierwszym etapie badań dokonano oceny wpływu dopłat z WPR na relacje dochodu $\mathrm{z}$ reprezentatywnego gospodarstw rolnego FADN przypadającego na osobę pełnozatrudnioną rodziny $\left(\mathrm{FWU}^{3}\right.$ ) względem dochodu pozarolniczego w Polsce, w latach 2004-2013. W pierwszym wariancie dochód z reprezentatywnego gospodarstwa rolnego FADN uwzględniał dopłaty otrzymane $\mathrm{z}$ funduszy WPR, które stanowiła suma dopłat do działalności operacyjnej oraz saldo dopłat i podatków do działalności inwestycyjnej, w drugim nie zawierał on wartości tych dopłat. Za dochód $\mathrm{z}$ sektorów pozarolniczych przyjęto średnie roczne wynagrodzenie brutto na jednego zatrudnionego w złotych, w poszczególnych latach okresu badawczego. Założono, że wzrost relacji dochodu reprezentatywnego gospodarstwa rolnego FADN, przypadającego na osobę pełnozatrudnioną rodziny do dochodu pozarolniczego w Polsce, w poszczególnych latach okresu 2004-2013, powoduje wzrost zrównoważenia ekonomicznego rolnictwa w Polsce, gdyż świadczy o polepszaniu się sytuacji dochodowej tego sektora względem pozostałych sektorów. Porównanie relacji dochodu $\mathrm{z}$ reprezentatywnego gospodarstwa rolnego FADN z dopłatami z WPR i po ich odjęciu, względem dochodu pozarolniczego w Polsce, pozwoliło nam wnioskować o wpływie dopłat $\mathrm{z}$ WPR na zrównoważenie ekonomiczne rolnictwa w Polsce w latach 2004-2013. Następnie przeprowadzono regresję panelową, w celu określenia, która z grup dopłat i subwencji z WPR w latach 2004-2013 najbardziej oddziaływała na wzrost zrównoważenia ekonomicznego rolnictwa w Polsce. Ponieważ analizowane dane były połączonymi danymi przekrojowymi (dla klas wielkości ekonomicznej) i danymi dotyczącymi szeregów czasowych (2004-2013), zbadano zależność dochodu netto z gospodarstwa rolnego w przeliczeniu na jednostkę pracy rodziny (FWU) od różnych grup subsydiów, przy użyciu regresji panelowej. Po analizie wykresu rozrzutu zdecydowano o zastosowaniu modelu potęgowego, wobec czego zlogarytmowano obie strony równania i otrzymano funkcję zmiennej zależnej $y$ :

$$
\begin{gathered}
\ln Y=\ln (X 1)+\ln (X 2)+\ln (X 3)+\ln (X 4) \\
\ln Y_{i t}=\alpha \ln X 1_{i t}+\beta \ln X 2_{i t}+\gamma \ln X 3_{i t}+\delta \ln X 4_{i t}+b_{i t}
\end{gathered}
$$

gdzie: $Y_{i t}$ - dochód netto z gospodarstwa rolnego w przeliczeniu na FWU w klasach wielkości ekonomicznej $i$ latach $t ; X 1_{i t}$ - wartość dopłat do dóbr publicznych (rozumiana jako suma płatności z tytułu odłogowania i rolnośrodowiskowych, wsparcia dla obszarów o niekorzystnych warunkach gospodarowania i innych

\footnotetext{
3 Jednostka przeliczeniowa pracy członków rodziny gospodarstwa rolnego (osób pełnozatrudnionych w gospodarstwie) (ang. Family Work Unit) (Floriańczyk i in. 2014, s. 4).
} 
dopłat w ramach programów wsparcia obszarów wiejskich w przeliczeniu na FWU); $X 2_{i t}$ - wartość dopłat do produkcji roślinnej i zwierzęcej (suma innych dopłat do produkcji roślinnej i zwierzęcej, salda dopłat i kar dla producentów mleka, dopłat do pozostałego bydła oraz dopłat do owiec i kóz w przeliczeniu na FWU); $X 3_{i t}-$ wartość jednolitych płatności obszarowych (JPO) w przeliczeniu na FWU; $X 4_{i t}-$ wartość dopłat do inwestycji w przeliczeniu na FWU.

Następnie skonstruowano zwykłe modele regresji klasyczną metodą najmniejszych kwadratów (KMNK). Ze względu na konieczność odrzucenia hipotezy zastosowania tego podejścia (opartej na teście Breuscha-Pagana) oszacowano model panelowy o stałych efektach (FE). Ocena, który z tych modeli (FE lub RE o stałych czy losowych efektach) jest właściwy, została przeprowadzona na podstawie testów Hausmana i Welcha. Ostateczny model oszacowano przy wykorzystaniu błędów standardowych HAC. Współliniowość zmiennych oceniono na podstawie współczynników inflacji wariancji (Varians Inflation Factors - VIF). Tylko jedna ze zmiennych (jednolite płatności obszarowe / FWU) nieco przekraczała wartość krytyczną VIF = 10, wobec czego uznano, że można przeprowadzić wnioskowanie na podstawie oszacowanego modelu. Na zakończenie tej części badań zastosowano jeszcze podział gospodarstw rolnych FADN według klas ekonomicznych, wyrażonych wartościami standardowej produkcji gospodarstwa rolnego w euro ${ }^{4}$, w celu odpowiedzi na pytanie, czy klasy te różniły się między sobą ze względu na oddziaływanie wsparcia z WPR na ich zrównoważenie ekonomiczne.

Następnie dokonano analizy porównawczej wpływu dopłat $z$ WPR na zrównoważenie ekonomiczne gospodarstw rolnych w Polsce o różnej sile ekonomicznej w latach 2005-2013, w stosunku do 2004 r., przyjmując go jako okres bazowy. W porównaniach zastosowano też dwa warianty. $\mathrm{W}$ pierwszym $\mathrm{z}$ nich dochód $\mathrm{z}$ gospodarstwa rolnego obejmował, jak poprzednio, wartość dopłat uzyskanych w ramach funduszy WPR, w drugim został on pomniejszony o tę wartość. Gospodarstwa reprezentatywne ponownie podzielono na sześć klas według wartości ich produkcji standardowej. W dalszej części porównano zmiany relacji dochodu z gospodarstwa rolnego, przypadającego na osobę pełnozatrudnioną rodziny $\mathrm{w}$ tych dwóch wariantach, względem dochodu pozarolniczego w Polsce (średnie roczne wynagrodzenie brutto na jednego zatrudnionego w złotych), w poszczególnych latach okresu 2005-2013, w stosunku do tej relacji występującej w 2004 r. Przyjęto, że podobny wpływ dopłat $\mathrm{z}$ WPR na relacje dochodów rolniczych do pozarolniczych

4 Wielkość ekonomiczna gospodarstwa jest wyrażana w jednostkach SO (Standard Output) i jest to średnia z 5 lat roczna wartość produkcji określonej działalności roślinnej lub zwierzęcej uzyskiwana $\mathrm{z}$ ha lub od 1 zwierzęcia, w przeciętnych dla danego regionu warunkach (Bocian, Cholewa, Tarasiuk 2014, s. 40,55$)$. 
względem tej relacji w 2004 r. w różnych klasach ekonomicznych gospodarstw świadczy o tym, iż żadna z tych klas w Polsce nie była uprzywilejowana w zakresie wpływu dopłat na zrównoważenie ekonomiczne, co przemawiałoby jednocześnie za zrównoważeniem społecznym samego rolnictwa w Polsce (jako że jednym z elementów zrównoważenia społecznego jest równomierny rozkład dochodów w badanej grupie). Tym samym asymetryczny wpływ dopłat na zrównoważenie ekonomiczne różnych klas gospodarstw, w latach 2005-2013 względem 2004 r., oznacza brak zrównoważenia społecznego gospodarstw rolnych w Polsce, gdyż korzyści z pozytywnego wpływu wsparcia z polityki rolnej UE są przechwytywane przez te klasy producentów, dla których dzięki dopłatom z WPR występuje największa różnica pomiędzy relacją dochodów rolniczych do dochodów pozarolniczych $\mathrm{w}$ wariacie $\mathrm{z}$ dopłatami i tą samą relacją $\mathrm{w}$ wariancie bez dopłat. Zakres czasowy badań objął lata 2004-2013, przestrzenny - Polskę, podmiotowy zaś - reprezentatywne gospodarstwa rolne FADN (spośród ok. 730 tys. gospodarstw w poszczególnych latach okresu badawczego).

\section{Wyniki i dyskusja}

Zanim przejdziemy do omówienia wyników badań, warto zastanowić się nad strukturą funduszy Unii Europejskiej, które trafiają do gospodarstw rolnych. I tak, możemy wskazać dwa cele takich środków - konkurencyjność i spójność. Cel pierwszy kładzie nacisk na wysoki i rosnący standard życia, tworzenie zatrudnienia, przy możliwie najniższym bezrobociu (European Commission 2003). Z kolei spójność dotyczy trzech wymiarów: gospodarczego, społecznego oraz przestrzennego i oznacza zmniejszenie zróżnicowań w poziomie rozwoju gospodarczego pomiędzy bogatymi i biednymi obszarami, ale można ją także odnieść do poszczególnych grup społecznych. Wydaje się, że zarówno wspieranie konkurencyjności, jak i spójności powinno prowadzić do zmniejszania się rozpiętości dochodów. De facto, o ile fundusze przeznaczane na wspomaganie spójności z dużym prawdopodobieństwem przyczyniają się do zmniejszania zróżnicowania na wielu płaszczyznach, także ekonomicznych, czyli m.in. dochodów, o tyle środki pomocowe mające na celu poprawę konkurencyjności nie oddziałują w jednoznaczny sposób na tworzenie dochodów. Wspieranie konkurencyjności może nieść ze sobą bowiem wzrost finansowania przede wszystkim większych obszarowo gospodarstw, o większych możliwościach rozwojowych i posiadających wkład własny na współfinansowanie projektów, co jednoznacznie wynika z celu wspierania konkurencyjności - osiągnięcia wysokiego poziomu produkcyjności (Graca-Gelert 2014). A jak jest w praktyce? W jaki sposób różnego rodzaju dopłaty wpływają na ogólny wzrost zamożności gospodarstw rolnych i zróżnicowanie poziomu dochodów wewnątrz badanej grupy? 
Przypomnijmy, że poprzez relację dochodu rolniczego do dochodu pozarolniczego zostanie zbadany poziom zrównoważenia ekonomicznego, natomiast określenie dysproporcji w tych relacjach dla różnych klas ekonomicznych gospodarstw rolnych będzie służyć zdefiniowaniu zrównoważenia społecznego.

W latach 2004-2013 uwzględnienie wartości dopłat z WPR powodowało, że dochody rolnicze stanowiły średnio ponad $66 \%$ przeciętnych dochodów w sektorach nierolniczych w Polsce. Nieuwzględnienie tego wsparcia w wartości dochodów rolniczych powodowało, że relacja ta była o ponad połowę niższa, wynosząc jedynie $29,3 \%$ (zob. tab. 1 ).

Tabela 1. Relacja dochodów rolniczych gospodarstw FADN do dochodów pozarolniczych w Polsce w latach 2004-2013

Table 1. Relation of FADN farm incomes to non-agricultural incomes in Poland in the years 2004-2013

\begin{tabular}{llllllllllll}
\hline $\begin{array}{c}\text { Relacja dochodów } \\
\text { rolniczych } \\
\text { do pozarolniczych } \\
(\mathbf{w} \%)\end{array}$ & 2004 & 2005 & 2006 & 2007 & 2008 & 2009 & 2010 & 2011 & 2012 & 2013 & Średnia \\
\hline Bez dopłat & 46,7 & 32,8 & 31,4 & 45,8 & 18,7 & 8,1 & 27,3 & 31,2 & 29,7 & 20,8 & 29,3 \\
Z dopłatami & 70,4 & 55,6 & 65,7 & 80,3 & 57,7 & 54,1 & 73,0 & 76,3 & 71,5 & 61,1 & 66,6 \\
\hline
\end{tabular}

Źródło: opracowanie własne na podstawie danych bazy FADN (fadn.pl).

Source: own studies on the basis of FADN database (fadn.pl).

Dzięki wsparciu przeciętne dochody gospodarstw rolnych FADN w Polsce zbliżały się do wartości przeciętnych dochodów sektorów nierolniczych, co z całą pewnością korzystnie wpływało na zrównoważenie ekonomiczne rolnictwa w Polsce. W latach 2004-2013 średnia wartość dochodów rolniczych bez dopłat z WPR w stosunku do wartości przeciętnych dochodów sektorów nierolniczych stanowiła zaledwie $29,3 \%$, a po uwzględnieniu wartości dopłat z WPR w dochodach rolniczych relacja ta wzrosła aż do 66,6\%. Jeszcze bardziej widoczne są różnice w relacjach dla kryzysowych lat 2008-2009. Gdyby gospodarstwa nie otrzymywały wówczas wsparcia, ich dochody stanowiłyby zaledwie 18,7 i 8,1\% dochodów pozarolniczych dla dwóch kolejnych okresów. Dzięki dotacjom stosunek ten wzrósł odpowiednio do 57,7\% i 54,1\%. Przytoczone wyniki badań potwierdzają analizy Agnieszki Baer-Nawrockiej (2013), zgodnie z którymi rozstrzygający wpływ na wzrost dochodu w krajach UE-12 miało objęcie rolnictwa instrumentami WPR. Wyróżnione w tej grupie kraje charakteryzowały się dużym wzrostem dotacji ogółem, przy czym największy dotyczył Polski. Autorka oszacowała, że udział dotacji ogółem w dochodach gospodarstw rolnych w Polsce w latach 2004-2007 wyniósł aż 45,8\%, 
w latach 2008-2011 zaś osiągnął jeszcze wyższy poziom - 52,3\%. Podobne konkluzje sformułowali Mirosław Drygas (2010) i Tadeusz Sobczyński (2008). Według nich w rezultacie wsparcia bezpośredniego w wielu krajach zmniejszyło się zróżnicowanie między dochodami rolników a dochodami uzyskiwanymi w innych grupach zawodowych.

Kolejnym etapem badania było oszacowanie, przy wykorzystaniu analizy panelowej, które programy WPR mają wpływ na dochody z gospodarstwa rolnego. Stwierdzono, że model z efektami stałymi okazał się być odpowiedni, co oznacza, że występują istotne statystycznie różnice pomiędzy wpływem poszczególnych grup subsydiów na dochody z gospodarstwa rolnego na FWU w poszczególnych klasach wielkości ekonomicznej. Model był dobrze dopasowany: uwzględnienie indywidualnych grup wielkości ekonomicznych powodowało, że wartość LSDV $\mathrm{R}^{2}$ wynosiła 0,99 . Była stała w czasie (ale różniła się w przestrzeni), a w przypadku „within $\mathrm{R}^{2 ”}$ - osiągnęła wartość 0,54 . Należy przypomnieć, że analizowano stos szeregów czasowych (lata 2004-2013 dla każdej grupy wielkości ekonomicznej), a zatem „within” przypisywało zmienność dochodów z gospodarstwa rolnego w przeliczeniu na FWU do zmiennych objaśniających, które zmieniały się także w czasie. Ich zmienność w czasie w modelu okazała się jednak nieistotna statystycznie. Wszystkie zmienne w modelu były statystycznie istotne (ich wartości p nie przekraczały $0,1, \mathrm{z}$ wyjątkiem płatności za dobra publiczne, dla których $\mathrm{p}=0,13$, więc były na granicy istotności).

$\mathrm{Z}$ modelu wynika, że jeśli najmniejszą istotnością dla wyjaśniania dochodu netto z gospodarstwa rolnego w przeliczeniu na FWU cechowały się dopłaty do dóbr publicznych, to mogło to być spowodowane ich zróżnicowaniem w ramach badanej grupy (wchodzą tu m.in. płatności: rolnośrodowiskowe, do obszarów o niekorzystnych uwarunkowaniach naturalnych ONW, dla gospodarstw ekologicznych, za zalesienia). Zaskakujący był ujemny współczynnik dopłat do produkcji na FWU. Po analizie danych zauważono jednakże, że wynikało to ze znaczącego udziału kar za przekroczone limity produkcyjne, przez co dopłaty te w gospodarstwach o stosunkowo dużej skali (i większych dochodach na FWU) nie stanowiły znacznego udziału w tworzeniu dochodu. Zgodnie z modelem zwiększenie jednolitej płatności obszarowej o $1 \% \mathrm{w}$ polskich gospodarstwach prowadzi do zwiększenia dochodu z gospodarstwa rolnego / FWU o 0,13\%, co stanowi największy współczynnik spośród badanych grup subwencji, choć wyniki badań Renaty Marks-Bielskiej i Karoliny Babuchowskiej (2009) dowiodły, że dopłaty bezpośrednie nie były przez rolników oceniane jako znaczące wsparcie finansowe ich gospodarstwa. Tendencje te (choć nie wartości wpływu) znalazły też potwierdzenie we wnioskach Piotra Gołasy (2010) z badania wpływu wybranych instrumentów WPR na kształtowanie się dochodów gospodarstw rolnych w Polsce. 
Tabela 2. Wpływ poszczególnych grup dopłat na dochód z gospodarstwa rolnego w latach 2004-2013 w świetle regresji panelowej (stałe efekty, robust HAC)

Table 2. Impact of specific groups of subsidies on farm income in the years 20042013 in the light of panel analysis (constant effects, robust HAC)

\begin{tabular}{lcccc}
\hline & Współczynnik & Błąd stand. & t-Studenta & Wartość $\mathbf{p}$ \\
\hline Const & 8,23485 & 0,801033 & 10,2803 & 0,0001 \\
$\begin{array}{l}\text { Ln dopłaty do dóbr publicznych } \\
\text { na FWU }\end{array}$ & 0,0792276 & 0,0450463 & 1,7588 & 0,1389 \\
$\begin{array}{l}\text { Ln dopłaty do produkcji } \\
\text { na FWU }\end{array}$ & $-0,141949$ & 0,059724 & $-2,3767$ & 0,0634 \\
Ln JPO na FWU & 0,137932 & 0,0551024 & 2,5032 & 0,0543 \\
$\begin{array}{l}\text { Ln dopłaty do inwestycji } \\
\text { na FWU }\end{array}$ & 0,0489927 & 0,0199134 & 2,4603 & 0,0572 \\
\hline $\begin{array}{l}\text { średn. aryt. zm. zależnej } \\
\text { Suma kwadratów reszt }\end{array}$ & 9,435998 & Odch. stand. zm. zależnej & 1,384141 \\
$\begin{array}{l}\text { LSDV R-kwadrat } \\
\text { Logarytm wiarygodności }\end{array}$ & 0,877131 & Błąd standardowy reszt & 0,146265 \\
Kryt. bayes. Schwarza & 0,990843 & Within R-kwadrat & 0,543599 \\
Autokorel. reszt - rho1 & $-23,15919$ & Kryt. inform. Akaike’a & $-42,47745$ \\
& 0,015184 & Stat. Durbina-Watsona & 1,843514
\end{tabular}

Źródło: opracowanie własne na podstawie danych bazy FADN (fadn.pl).

Source: own studies on the basis of FADN database (fadn.pl).

W odniesienie do podziału gospodarstw na klasy ekonomiczne, dzięki dopłatom z WPR w latach 2004-2013 następował wzrost relacji dochodów rolniczych do pozarolniczych w każdej takiej klasie, jednakże wpływ ten był zróżnicowany i kształtował się od prawie 9 punktów procentowych w gospodarstwach najmniejszych aż do 2000 punktów procentowych w gospodarstwach największych. Charakterystyczne było to, że im większa produkcja gospodarstwa, określająca jego przynależność do danej klasy ekonomicznej, tym wyższy był korzystny wpływ dopłat z WPR na zrównoważenie ekonomiczne tego gospodarstwa. Asymetria w tym zakresie była bardzo duża, o czym świadczą chociażby różnice w zakresie oddziaływania dopłat $\mathrm{z}$ WPR na relacje dochodów rolniczych do pozarolniczych w gospodarstwach najmniejszych, jak i największych (zob. tab. 3). W związku z tym można stwierdzić, że dzięki wsparciu przeciętne dochody gospodarstw rolnych zbliżały się do przeciętnego dochodu w sektorach nierolniczych, ale dystrybucja tego wsparcia była bardzo nierówna wśród gospodarstw na korzyść gospodarstw większych. Prowadziło to do wzrostu dysproporcji dochodowych pomiędzy małymi, średnimi i dużymi gospodarstwami rolnymi w Polsce. 
Tabela 3. Relacja dochodów rolniczych do pozarolniczych dla różnych klas wielkości ekonomicznej (SO) gospodarstw FADN w Polsce - wartości średnie dla lat 20042013 (w \%)

Table 3. Relation of agricultural to non-agricultural incomes for different economic sizes (SO) of FADN farms in Poland - average values for the years 2004-2013 (in \%)

\begin{tabular}{|c|c|c|c|c|c|c|}
\hline $\begin{array}{l}\text { Relacja dochodów } \\
\text { rolniczych do } \\
\text { pozarolniczych } \\
\text { w latach 2004- } \\
2013 \text { (w \%) }\end{array}$ & $\begin{array}{l}\text { Do } 8 \text { tys. } \\
\text { EUR SO }\end{array}$ & $\begin{array}{c}8-25 \text { tys. } \\
\text { EUR SO }\end{array}$ & $\begin{array}{c}25-50 \text { tys. } \\
\text { EUR SO }\end{array}$ & $\begin{array}{l}50-100 \text { tys. } \\
\text { EUR SO }\end{array}$ & $\begin{array}{c}100-500 \text { tys. } \\
\text { EUR SO }\end{array}$ & $\begin{array}{l}\text { Powyżej } \\
500 \text { tys. } \\
\text { EUR SO }\end{array}$ \\
\hline Bez dopłat & 16,6 & 19,3 & 59,2 & 106,2 & 614,5 & $-794,0$ \\
\hline Z dopłatami & $25,5^{*}$ & 47,8 & 106,0 & 182,9 & 788,8 & 1205,6 \\
\hline $\begin{array}{l}\text { Wzrost relacji } \\
\text { przez wsparcie } \\
\text { z WPR w punktach } \\
\text { procentowych }\end{array}$ & 8,9 & 28,5 & 46,8 & 76,7 & 173,5 & 1999,7 \\
\hline
\end{tabular}

* Wynik ten jest zbliżony do wyniku badań Lecha Goraja (2005, za: Chmielewska 2007, s. 32). Według autora relacja dochodów rolniczych z dopłatami w przeliczeniu na osobę pełnozatrudnioną względem średniej płacy netto w gospodarce narodowej w gospodarstwach najmniejszych (najsłabszych ekonomicznie) w 2004 r. wyniosła $22 \%$.

Źródło: opracowanie własne na podstawie danych bazy FADN (fadn.pl).

Source: own studies on the basis of FADN database (fadn.pl).

Tym samym potwierdzona została przyjęta we wstępie hipoteza badawcza. Jest ona również spójna z wnioskami badań Joanny Bereżnickiej (2011), według których różnice w wysokości dochodów między różnymi grupami gospodarstw są duże, przy czym na ich wysokość nie wpływały tylko poziomy dopłat, ale także dysponowanie przez najsilniejsze gospodarstwa zasobami umożliwiającymi osiąganie wysokich poziomów produkcji. Autorka wykazała również, że w gospodarstwach bardzo dużych występuje silna współzależność jednokierunkowa pomiędzy wartością dochodu a dopłatami. Z kolei Patrycja Graca-Gelert (2014) wykazała, że w latach 2005-2010 dopłaty bezpośrednie pogłębiały zróżnicowanie dochodów, natomiast renty strukturalne od 2007 r. przyczyniały się do ograniczania nierówności dochodów w Polsce. Ponieważ jednak dopłaty bezpośrednie stanowią największą część wsparcia gospodarstw rolnych, stąd ogólnie zauważalny był wzrost dysproporcji w dochodach. Na stały wzrost nierówności dochodowych wskazuje również Ryszard Szarfenberg (2015), co wynika z systemu naliczania dopłat: większe gospodarstwa otrzymują większe dopłaty, niewielkie zaś pozyskują symboliczne kwoty.

O tym, że w polskim rolnictwie występuje asymetria w zakresie podziału korzyści ze wsparcia gospodarstw w ramach polityki rolnej UE, świadczą wyniki obliczeń zamieszczone w tabeli 3. Celem dalszej analizy jest określenie, czy asymetria 
występowała także w zakresie wpływu dopłat $\mathrm{z}$ WPR na zrównoważenie ekonomiczne poszczególnych klas gospodarstw FADN w latach 2004-2013.

Na rysunku 1 przedstawiono wpływ dopłat i subwencji z WPR na zmiany zrównoważenia ekonomicznego gospodarstw rolnych FADN w Polsce, mierzone relacją ich dochodów względem dochodów w sektorach nierolniczych w latach 2005-2013, w stosunku do tej relacji w 2004 r. $(2004=100)$. Widać wyraźnie, że wpływ ten był nierównomierny w różnych klasach gospodarstw, na co najwyraźniej wskazuje porównanie sytuacji dochodowej gospodarstw najmniejszych i należących do największej klasy ekonomicznej. Otóż w gospodarstwach najmniejszych można mówić o zwiększeniu ich zrównoważenia ekonomicznego, mierzonego relacją ich dochodów FWU do dochodu pozarolniczego, o 45,6\% średnio w okresie 2004-2013 $\mathrm{w}$ wariancie bez dopłat i o 6,2\%, gdyby w dochodach uwzględniono dopłaty (niższy wzrost $\mathrm{w}$ wariancie $\mathrm{z}$ dopłatami nie oznacza niższego wzrostu w ujęciu absolutnym). W związku z tym należy stwierdzić, że uwzględnienie subwencji WPR $\mathrm{w}$ dochodach rolniczych tych gospodarstw tylko w niewielkim stopniu prowadziło do poprawy ich zrównoważenia ekonomicznego. Interesujące jest spostrzeżenie, że gospodarstwa najmniejsze jako jedyne zbliżyły się pod względem dochodów do gospodarstw nierolniczych bez względu na uwzględnienie lub pominięcie dopłat w tych dochodach (różnica pomiędzy dwoma wariantami wynosiła 39 punktów procentowych na korzyść wariantu bez dopłat).

W pozostałych klasach ekonomicznych gospodarstw, bez względu na przyjęty wariant, poziom zrównoważenia ekonomicznego w latach 2004-2013 uległ obniżeniu (jeśli za podstawę przyjmiemy rok 2004), przy czym dopłaty w znaczącym stopniu ograniczały spadek niekorzystnej relacji dochodów rolniczych do pozarolniczych (por. rys. 1). Otóż brak włączenia dopłat przy obliczaniu relacji dochodu rolniczego do pozarolniczego w latach 2004-2013 (dla $2004=100$ ) skutkował spadkiem tej relacji średnio o 64\%, a w przypadku gospodarstw największych aż o 167\%. Uwzględnienie wartości dopłat w dochodach zmniejszyło wspomniany spadek średnio do poziomu $22 \%$, a w gospodarstwach największych do $40 \%$. Tym samym gospodarstwa największe „zyskały” na wsparciu 127 punktów procentowych (to znaczy o tyle mniej spadła relacja ich dochodów do dochodów pozarolniczych) i to one były głównymi beneficjentami funduszy WPR. Dla pozostałych klas ekonomicznych tak obliczone rozpiętości wahały się od 9 punktów procentowych w grupie gospodarstw 100-500 tys. euro SO do 36\% punktów procentowych w grupie 8-25 tys. euro. Poziom zróżnicowania wsparcia można ukazać także poprzez określenie udziału dopłat $\mathrm{w}$ dochodach rolniczych (łącznie $\mathrm{z}$ dopłatami) ocenianych gospodarstw. I tak, zdecydowanie najwyższy udział wsparcia średnio dla lat 2004-2013 zanotowano w przypadku gospodarstw największych, tutaj też najwyższy był wzrost tego udziału w analizowanym okresie (por. tab. 4). Na drugim 
Oddziaływanie Wspólnej Polityki Rolnej na zrównoważenie ekonomiczno-społeczne..


zmiana relacji dochodów w kolejnych latach w wariancie bez dopłat zmiana relacji dochodów w kolejnych latach w wariancie z dopłatami

zmiana relacji dochodów średnio dla lat 2005-2013 w wariancie bez dopłat

zmiana relacji dochodów średnio dla lat 2005-2013 w wariancie z dopłatami

Rysunek 1. Zmiana relacji dochodów rolniczych do pozarolniczych w różnych klasach ekonomicznych gospodarstw FADN w Polsce w latach 2005-2013, dla $2004=100$ (w \%)

Figure 1. Change of relation of agricultural to non-agricultural incomes for different economic sizes (SO) of FADN farms in Poland in the years 2005-2013, $2004=100$ (in \%)

Źródło: opracowanie własne na podstawie danych FADN (fadn.pl).

Source: own studies on the basis of FADN database (fadn.pl). 
miejscu znalazła się grupa gospodarstw o wielkości ekonomicznej 8-25 tys. euro SO, a dalej 25-50 tys. euro i 50-100 tys. euro. Z danych wynika ponadto, że tylko w grupie gospodarstw najmniejszych relacja dopłat do dochodu rolniczego spadła w badanym okresie, co może świadczyć o braku zrównoważenia społecznego w ujęciu nie tylko statycznym, ale również dynamicznym.

Tabela 4. Udział dopłat WPR w dochodach rolniczych i zmiana tego udziału w okresie 2004-2013 dla różnych grup wielkości ekonomicznej (SO) gospodarstw FADN w Polsce

Table 4. Share of CAP subsidies in agricultural incomes and change thereof in the period 2004-2013 for different groups of economic size (SO) of FADN farms in Poland

\begin{tabular}{lcccccc}
\hline \multicolumn{1}{c}{ Wyszczególnienie } & $\begin{array}{c}\text { Do } 8 \text { tys. } \\
\text { EUR SO }\end{array}$ & $\begin{array}{c}\mathbf{8}-\mathbf{2 5} \text { tys. } \\
\text { EUR SO }\end{array}$ & $\begin{array}{c}\mathbf{2 5 - 5 0} \text { tys. } \\
\text { EUR SO }\end{array}$ & $\begin{array}{c}\mathbf{5 0 - 1 0 0} \text { tys. } \\
\text { EUR SO }\end{array}$ & $\begin{array}{c}\mathbf{1 0 0 - 5 0 0} \\
\text { tys. EUR SO }\end{array}$ & $\begin{array}{c}\text { Powyżej } \\
\mathbf{5 0 0} \text { tys. } \\
\text { EUR SO }\end{array}$ \\
\hline $\begin{array}{l}\text { Udział dopłat } \\
\begin{array}{l}\text { w dochodzie rolniczym } \\
\text { średnio 2004-2013 }\end{array}\end{array}$ & $36 \%$ & $62 \%$ & $46 \%$ & $41 \%$ & $22 \%$ & $159 \%$ \\
$\begin{array}{l}\text { Zmiana średniego } \\
\text { udziału dopłat } \\
\text { w stosunku do 2004 r. }\end{array}$ & $-16 \%$ & $35 \%$ & $26 \%$ & $21 \%$ & $10 \%$ & $215 \%$ \\
\hline
\end{tabular}

Źródło: opracowanie własne na podstawie danych FADN (fadn.pl).

Source: own studies on the basis of FADN database (fadn.pl).

\section{Wnioski}

W niniejszej pracy autorzy starali się znaleźć odpowiedź na pytanie o wpływ WPR na poziom zrównoważenia ekonomiczno-społecznego gospodarstw rolnych w Polsce. Spośród wielu mierników oraz wskaźników zrównoważenia przyjęli poziom dochodów rolniczych w relacji do dochodów pozarolniczych jako element ekonomiczny trwałego rozwoju oraz stopień zróżnicowania wsparcia (a więc i dochodów) jako element społeczny. Na podstawie obserwacji danych FADN i własnych wyliczeń sformułowano następujące konkluzje:

- dzięki wsparciu otrzymanemu w ramach funduszy WPR przeciętne dochody gospodarstw rolnych zbliżają się do przeciętnego dochodu sektora nierolniczego;

- wszystkie cztery oceniane grupy wsparcia WPR (tj. jednolite płatności obszarowe, dopłaty do produkcji, dopłaty do dóbr publicznych, wsparcie inwestycji) okazały się istotne dla kształtowania dochodów rolniczych; największy wpływ na wzrost dochodów rolniczych w badanym okresie miały jednolite płatności 
obszarowe, a w dalszej kolejności subwencje dla dóbr publicznych i dopłaty do inwestycji;

- w każdej klasie ekonomicznej gospodarstw rolnych nastąpił wzrost relacji dochodów rolniczych do pozarolniczych dzięki wsparciu finansowanemu z polityki rolnej UE, przy czym w najmniejszym stopniu dotyczyło to najsłabszych ekonomicznie podmiotów; w miarę wzrostu siły ekonomicznej gospodarstwa wpływ dotacji WPR na zbliżanie się do poziomu dochodu pozarolniczego był mocniejszy;

- wpływ dopłat WPR na zmiany zrównoważenia ekonomicznego był nierównomierny w różnych klasach gospodarstw - w największym stopniu zyskały gospodarstwa najsilniejsze; $\mathrm{z}$ drugiej strony tylko w gospodarstwach najsłabszych ekonomiczne spadła relacja dopłat do dochodu rolniczego;

Reasumując, należy stwierdzić, że przeprowadzone badania potwierdziły przyjętą hipotezę: transfery finansowane $w$ ramach WPR poprawiają ogólny poziom zrównoważenia ekonomicznego sektora rolnego, nie są jednak instrumentem służącym wyrównywaniu dochodów (jako element społeczny zrównoważenia) pomiędzy gospodarstwami rolnymi.

\section{Bibliografia}

Baer-Nawrocka A. (2013). Wpływ Wspólnej Polityki Rolnej na efekty dochodowe w rolnictwie nowych krajów członkowskich. Zeszyty Naukowe SGGW w Warszawie. Polityki Europejskie, Finanse i Marketing, 58 (9), 34-44.

Bereżnicka J. (2011). Dopłaty a możliwość osiągnięcia dochodu w gospodarstwach rolnych. Zeszyty Naukowe Uniwersytetu Szczecińskiego. Finanse, Rynki Finansowe, Ubezpieczenia, 640 (38), 16-18.

Bocian M., Cholewa I., Tarasiuk R. (2014). Wspótczynniki Standardowej Produkcji „2010” do celów Wspólnotowej Typologii Gospodarstw Rolnych. Warszawa: Instytut Ekonomiki Rolnictwa i Gospodarki Żywnościowej - PIB.

Bossel H. (1999). Indicators for sustainable development: Theory, method, applications. Winnipeg: International Institute of Sustainable Development.

Cauwenbergh N. van, Biala K., Bielders C., Brouckaert V., Franchois L., Garcia Cidad V., Hermy M., Mathijs E., Muys B., Reijnders J., Sauvenier X., Valckx J., Vanclooster M., van der Veken B., Wauters E., Peeters A. (2007). SAFE - A hierarchical framework for assessing the sustainability of agricultural systems. Agriculture, Ecosystems \& Environment, $120(2-4), 229-242$.

Chmielewska B. (2007). Płatności bezpośrednie jako forma wsparcia dochodów gospodarstw rolniczych w Polsce po integracji z Unią Europejską. Zeszyty Naukowe SGGW $w$ Warszawie. Problemy Rolnictwa Światowego, 17 (2), 28-34. 
Commission of the European Communities (2001). A Sustainable Europe for a Better World: A European Union Strategy for Sustainable Development, COM(2001)264 final. Brussels.

Czyżewski B. (2017). Kierat rynkowy w europejskim rolnictwie. Warszawa: Wydawnictwo Naukowe PWN.

Drygas M. (2010). Wpływ dopłat bezpośrednich w ramach Wspólnej Polityki Rolnej 20042006 i 2007-2013 na przekształcenia obszarów wiejskich $w$ województwie pomorskim (ekspertyza wykonana na zamówienie Urzędu Marszałkowskiego w Gdańsku). Warszawa: Instytut Rozwoju Wsi i Rolnictwa PAN.

European Commission (2003). European Competitiveness Report 2003, Commission Staff Working Document, No. SEC(2003)1299. Brussels.

European Commission (2010). Communication from the Commission: Europe 2020. A strategy for smart, sustainable and inclusive growth, $\operatorname{COM}(2010) 2020$. Brussels.

Eurostat (2017). Sustainable Development Indicators, http://ec.europa.eu/eurostat/web/ sdi/indicators/socioeconomic-development [dostęp: 15.03.2017].

Floriańczyk Z., Mańko S., Osuch D., Płonka R. (2014). Wyniki Standardowe 2013 uzyskane przez gospodarstwa rolne uczestniczace w Polskim FADN Część I. Wyniki Standardowe. Warszawa: Instytut Ekonomiki Rolnictwa i Gospodarki Żywnościowej - PIB.

Gołasa P. (2010). Wpływ wybranych instrumentów Wspólnej Polityki Rolnej na kształtowanie się dochodów gospodarstw rolnych w Polsce. Zeszyty Naukowe SGGW w Warszawie. Polityki Europejskie, Finanse i Marketing, 53 (4), 173-180.

Goraj L. (2005). Wpływ płatności bezpośrednich na dochody polskich gospodarstw rolnych. Warszawa: Urząd Komitetu Integracji Europejskiej.

Graca-Gelert P. (2014). Wpływ funduszy unijnych na zróżnicowanie dochodów w Polsce przykład dopłat bezpośrednich i rent strukturalnych. Nierówności Społeczne a Wzrost Gospodarczy, 38, 180-190.

Graczyk A. (2007). Zrównoważony rozwój w teorii ekonomii i w praktyce. Wrocław: Wydawnictwo Akademii Ekonomicznej im. Oskara Langego (seria Prace Naukowe AE im. Oskara Langego we Wrocławiu, nr 1190).

GUS - Urząd Statystyczny w Katowicach (2011). Wskaźniki zrównoważonego rozwoju $w$ Polsce. Katowice.

Hontelez J., Buitenkamp M. (2006). EU Sustainable Development Strategy: From theory to delivery. European Environmental Bureau: Brussels.

Latruffe L. (2010). Competitiveness, productivity and efficiency in the agricultural and agri-food sectors. OECD Food, Agriculture and Fisheries Working Papers, 30, 12-30.

Latruffe L., Diazabakana A., Bockstaller Ch, Desjeux Y., Finn J., Kelly E., Ryan M., Uthes S. (2016). Measurement of sustainability in agriculture: A review of indicators. Studies in Agricultural Economics, 118, 123-130.

Lebacq T., Baret P.V., Stilmant D. (2013). Sustainability indicators for livestock farming. A review. Agronomy for Sustainable Development, 33, 311-327.

Marks-Bielska R., Babuchowska K. (2009). Wsparcie dochodów rolników w formie dopłat bezpośrednich. Zeszyty Naukowe SGGWw Warszawie. Ekonomika i Organizacja Gospodarki Żywnościowej, 75, 135-148. 
Massot A. (2016). The Common Agricultural Policy (CAP) and the Treaty. http://www. europarl.europa.eu/atyourservice/en/displayFtu.html?ftuId=FTU_5.2.1.html [dostęp: 12.03.2017].

Mazur-Wierzbicka E. (2006). Miejsce zrównoważonego rozwoju w polskiej i unijnej polityce ekologicznej na początku XXI wieku. Nierówności Społeczne a Wzrost Gospodarczy, 8, 317-328.

Peacock W.G., Hoover G.A., Kilian C.D. (1988). Divergence and convergence in International development: A decomposition analysis of inequality in the World system. American Sociological Review, 6, 843.

Poczta-Wajda A. (2016). Interest groups and rent seeking in agriculture - a theoretical approach. W: B. Czyżewski (red.). Political rents of European farmers in the Sustainable Development Paradigm. International, National and regional perspective (s. 48-58). Warszawa: Wydawnictwo Naukowe PWN.

Sebaldt M. (red.) (2002). Sustainable Development - Utopie oder realistische Vision? Hamburg: Verlag Kovac.

Sen A.K. (1992). Inequality Reexamined. Oxford: Oxford University Press.

Sobczyński T. (2008). Zmiany udziału dopłat w dochodach gospodarstw rolniczych UE w latach 1989-2005. W: D. Kopycińska (red.). Polityka Unii Europejskiej (s. 36-50). Szczecin: Wydawnictwo Uniwersytetu Szczecińskiego.

Szarfenberg R. (2015). Nierówności i ubóstwo a uczestnictwo Polski w Unii Europejskiej. Warszawa: Instytut Polityki Społecznej Uniwersytetu Warszawskiego.

United Nations (1992). Report of the United Nations Conference on Enviroment and Development. Rio de Janeiro: United Nations publication, sales no. E.93.I.8 and corrigenda, vol. I.

Vrolijk H., Poppe K., Keszthelyi Sz. (2016). Collecting sustainability data in different organisational settings of the European Farm Accountancy Data Network. Studies in Agricultural Economics, 118, 138-144.

World Commission on Environment and Development (1987). Report of the World Commission on Environment and Development: Our Common Future. Oxford: Oxford University Press.

Zabłocki G. (2002). Rozwój zrównoważony. Idee, efekty, kontrowersje. Toruń: Wydawnictwo Uniwersytetu Mikołaja Kopernika.

Żmija D. (2014). Zrównoważony rozwój rolnictwa i obszarów wiejskich w Polsce. Studia Ekonomiczne, 166, 149-158. 


\title{
The Impact of the Common Agricultural Policy on the Socio-Economic Sustainability of Farms. An Example of Poland
}

\begin{abstract}
The concept of sustainable development emerged in the second half of the twentieth century and played an important role in determining the relationship between economic growth, social development and environmental care. In the first stage of paradigm formation the superiority of environmental issues was recognized, but as the globalization progressed, negative economic and social effects of uneven distribution of income, poverty and social exclusion began to reveal. This issue was also recognized at the European Union level, by i.a. creating sectoral policies, including the Common Agricultural Policy (CAP). One of the most important assumptions of the former and current CAP is to guarantee a decent standard of living for the agricultural population through various forms of support. In order to uphold sustainability, support mechanisms should be designed in such a way as to ensure simultaneously a high level of agricultural income (economic component), a relatively equal distribution of money among agricultural producers (social component) and care for natural resources (environmental component). The aim of this article is to define the impact of the CAP on the level of economic and social sustainability of agricultural holdings in Poland. The authors hypothesize that existing solutions serve to achieve economic sustainability (defined by the ratio of agricultural income to non-agricultural income), but do not balance agricultural holdings with respect to the social component (taking into account income disparities). Methods used in the paper include critical analysis of the literature, meta-analysis, inductive inference methods, as well as selected methods of quantitative analysis - regression and panel analysis. The subject area covers agricultural holdings belonging to Farm Accountancy Data Network (FADN) system, the time range embracing the period 2004-2013.
\end{abstract}

Keywords: socio-economic sustainability, Common Agricultural Policy, farms of FADN, Poland. 